\title{
Obstetric Referrals to a Tertiary Teaching Hospital of Nepal
}

Maskey S

Department of Obstetrics and Gynaecology, Institute of Medicine, Tribhuvan University Teaching Hospital, Kathmandu, Nepal

Received: March 05, 2014; Accepted: January 10, 2015

Aims: This study was done to review the primary reasons and pattern of obstetric cases referred to Tribhuvan University Teaching Hospital, and to identify the clinical course, mode of management, maternal and perinatal outcomes.

Methods: This prospective observational study reviewed 112 obstetric cases referred from various centers. Thorough history was taken; complete physical and obstetric examination and relevant investigations were done. Management of the patient, clinical course, mode of delivery, both maternal and perinatal outcomes were documented.

Results: Most common diagnosis at referral was medical disorders complicating pregnancy (38\%) among which cardiac disease accounted for $20 \%$, followed by hypertensive disorder (17\%). Unavailability of perinatal facility was the most frequent reason (24\%) for referral. Twenty seven percent of the patients were in serious or critical condition on arrival, $52 \%$ patients required surgical intervention, $19 \%$ received intensive care management and there were mortalities of 2 women ( $1.8 \%$ ). Total number of live births were $70(62.5 \%)$ among which $28(42 \%)$ required neonatal admission and 3 (4\% of live birth) had early neonatal death.

Conclusions: Wide spectrum of complicated obstetric cases were referred to this hospital. Unavailability of perinatal facility was the most common reason for referral followed by unavailability of physician. Most common diagnosis at the time of referral was medical disorders complicating pregnancy.

Keywords: eclampsia; obstetrics; referred cases.

\section{INTRODUCTION}

The referral system is an essential component of any health systems which is particularly important in pregnancy and childbirth for providing access to essential obstetric care. Even though pregnancy and childbirth are physiological processes bringing happiness to a couple these are associated with risks and complications, sometimes taking life of a woman and her baby if they are not taken care of in time. Especially in developing country like Nepal, major population lives in rural areas lacking access to essential obstetric facilities. In such areas timely referral and intervention of high risk and complicated obstetric cases can reduce maternal morbidity and avoid maternal deaths. However lack of structured referral system is a major hurdle in Nepal that delays proper management of such cases.

\section{CORRESPONDENCE}

Dr Suvana Maskey

Department of Obstetrics and Gynaecology;

Institute of Medicine, Tribhuvan University Teaching Hospital,

Kathmandu, Nepal.

E mail: suvanashrestha@yahoo.com

Phone: +9779851139574
Tribhuvan University Teaching Hospital (TUTH) is a tertiary care hospital, located in Kathmandu, which receives and manages a wide spectrum of complicated obstetric cases that are referred from different centers from all over Nepal and from India. This study was done as there is minimum or no data available concerning the varieties of referred obstetric cases managed in TUTH.

The objective of the study was to review the reasons for referral and patterns of obstetric cases referred to our hospital, to study the clinical course and management of women during the hospital stay and to study the maternal and perinatal outcomes (in terms of live birth or stillbirth, intrauterine fetal death, and neonatal admission).

\section{METHODS}

This was a prospective observational study carried out from $1^{\text {st }}$ October 2011 to $30^{\text {th }}$ September 2012. All referred obstetric cases that were managed in emergency or admitted to the Department of Obstetrics and Gynaecology of TUTH during the study period were included. Permission from the 
Department of Obstetrics and Gynaecology was taken before starting the study. Patients were explained about the purpose of the study and were included only after taking informed written consent.

Those cases that required admission and immediate management were taken. Thorough history of the patients who had been referred from different centers in Nepal was taken, taking note of the referring center and reason for referral. All collected data was filled in a predefined proforma. Complete physical and obstetric examination was done. Patient's clinical condition on arrival was classified - according to American Hospital Association. ${ }^{1}$ Basic investigations like complete blood count, urine routine and obstetric ultrasonography as well as case specific investigations were carried out as mandated by the clinical condition of the patient. Management of the patient (whether conservative or interventional) and mode of delivery (whether vaginal or operative) were noted. Fetal outcome parameters like abortion, live/ still birth, intra uterine fetal death (IUFD), Apgar score at 5 minute, neonatal admission and mortalities were noted. Patient was followed up until discharge and condition of mother on discharge, any maternal morbidity or catastrophe were also noted.

\section{RESULTS}

TUTH received and managed 112 women with various obstetric as well as associated medical and surgical conditions referred during the study period which constitutes $2.6 \%$ of total admission. Among them 58 (51.8\%) came from rural area and 54 (48.2\%) from urban area. Sixty four (57.14\%) of the patients were referred from various centers outside Kathmandu and 48 (42.86\%) from within Kathmandu Valley. Maximum cases $(48,42.86 \%)$ were referred from government hospitals (Table 1 ).

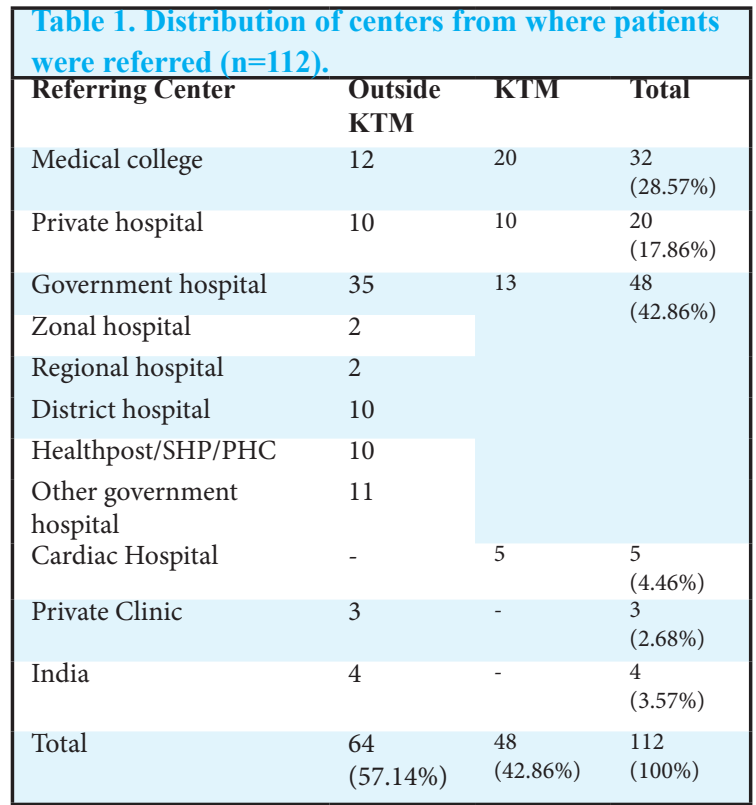

Ninety eight patients (87.5\%) arrived directly to TUTH whereas 14 (12.5\%) patients went to other hospitals and were then referred to TUTH. Ninety seven patients (86.6\%) were referred by doctor, and rest by nurse, health workers and paramedics. Referral slip was not available in 13 (11.6\%) cases and prior information via phone call was received only in $8(7 \%)$ cases.

The mean age of the patients was 25.2 years while age ranged from 15 years to 40 years. Mean period of gestation was 34.35 weeks and 70 (62.5\%) cases were $<37$ weeks. Concerning pregnancy status 62 (55.35\%) patients were antepartum, 32 (28.57\%) were intrapartum, 8 (7.14\%) postpartum, 10 (9\%) early pregnancy. Most common diagnosis for referral was medical disorders complicating pregnancy (42, $37.5 \%)$ among which cardiac disease accounted for 22 cases $(19.64 \%)$, followed by hypertensive disorder which was 18 (16\%) as shown in (Table 2). 


\begin{tabular}{|c|c|c|c|c|}
\hline $\begin{array}{l}\text { Table 2. Pa } \\
\text { referred cas }\end{array}$ & $\begin{array}{l}\text { atterns of diffe } \\
\text { es }(n=112) \text {. }\end{array}$ & rent con & & among \\
\hline Diagnosis & & & No & Total \\
\hline Medial & Hypertensive & Eclampsia & 5 & $(\%)$ \\
\hline $\begin{array}{l}\text { disorders } \\
\text { complicating } \\
\text { pregnancy }\end{array}$ & disorder & $\begin{array}{l}\text { Severe } \\
\text { Pre- } \\
\text { eclampsia }\end{array}$ & 12 & (16) \\
\hline & & $\begin{array}{l}\text { Chr. } \\
\text { HTN }\end{array}$ & 1 & \\
\hline & $\begin{array}{l}\text { Cardiac } \\
\text { disease }\end{array}$ & RHD & 18 & $\begin{array}{l}22 \\
(19.64)\end{array}$ \\
\hline & & $\begin{array}{l}\text { Cong } \\
\text { HD }\end{array}$ & 3 & \\
\hline & & $\begin{array}{l}\text { Peri } \\
\text { Partum }\end{array}$ & 1 & \\
\hline & Pancytopenia & DCM & & $\begin{array}{l}2 \\
(1.79)\end{array}$ \\
\hline $\begin{array}{l}\text { Obstetric } \\
\text { hemorrhage }\end{array}$ & $\begin{array}{l}\text { Antepartum } \\
\text { hemorrhage }\end{array}$ & & $\begin{array}{l}6 \\
3\end{array}$ & $\begin{array}{l}9 \\
(8)\end{array}$ \\
\hline & Secondary PPH & & & \\
\hline $\begin{array}{l}\text { Labor } \\
\text { abnormalities }\end{array}$ & $\begin{array}{l}\text { Obstructed } \\
\text { labor leading } \\
\text { to bladder rupture }\end{array}$ & & 1 & $\begin{array}{l}8 \\
(7.14)\end{array}$ \\
\hline & Prolonged labor & & 5 & \\
\hline & Preterm Labour & & 2 & \\
\hline $\begin{array}{l}\text { Early } \\
\text { pregnancy } \\
\text { conditions }\end{array}$ & & & & $\begin{array}{l}10 \\
(8.9)\end{array}$ \\
\hline PROM & Term PROM & & 3 & 8 \\
\hline & Preterm PROM & & 5 & (7.14) \\
\hline $\begin{array}{l}\text { Infective } \\
\text { conditions }\end{array}$ & & & & $\begin{array}{l}5 \\
(4.46)\end{array}$ \\
\hline $\begin{array}{l}\text { Mal } \\
\text { presentation }\end{array}$ & & & & $\begin{array}{l}4 \\
(3.57)\end{array}$ \\
\hline $\begin{array}{l}\text { Pregnancy } \\
\text { with } \\
\text { surgical } \\
\text { conditions }\end{array}$ & & & & $\begin{array}{l}7 \\
(6.25)\end{array}$ \\
\hline Miscellaneous & & & & $19(17)$ \\
\hline
\end{tabular}

Unavailability of perinatal facility was the most frequent reason for referral (Figure1).

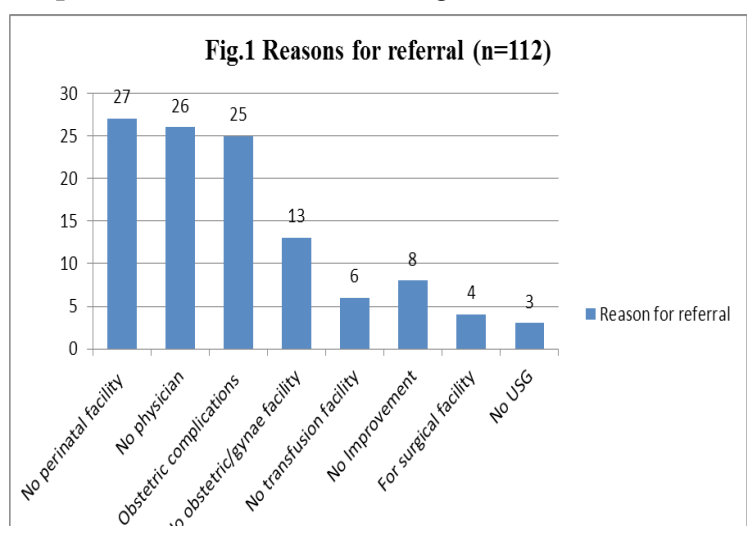

Eighty six patients $(76.79 \%)$ had done antenatal checkup. According to American Hospital Association's Classification, 5 (4.46\%) patients were in critical condition, $25(22.32 \%)$ in serious and rest $(82,73 \%)$ were in good condition at the time of admission. Fifty eight (51.79\%) patients required surgical intervention and 21 patients (18.75\%) received intensive care management. In addition to obstetric management nonobstetric management from other specialties (physician, surgeon) was required in 36 (32.14\%) patients (Table 3 ).

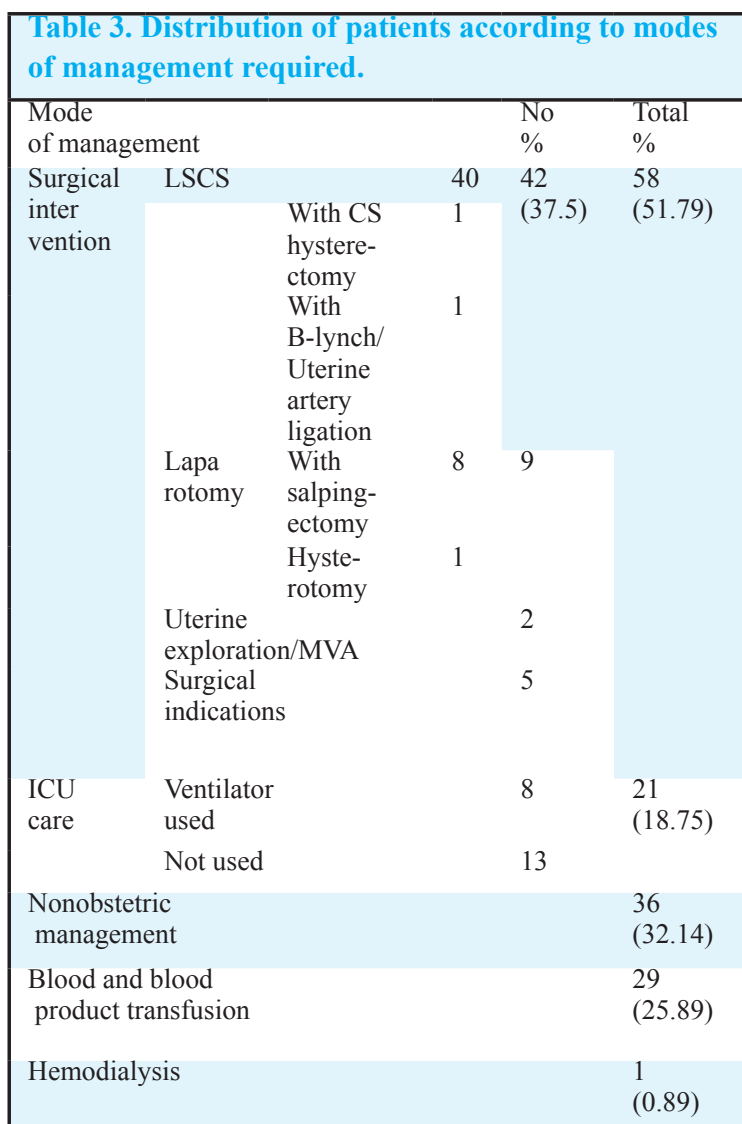

*The same patient had received multiple modalities of treatment (eg. Same patient had received blood transfusion, ICU care and surgical intervention)

Majority of patients $(69,61.61 \%)$ stayed for $<7$ days but $13(11.61 \%)$ patients were treated for $>21$ days (maximum 66 days). The mean duration was 10.54 days.

There were 2 mortalities during the study period among which one was in 34 year Para4+1 woman because of secondary post partum hemorrhage (PPH) with sepsis following vaginal delivery at home. Another was in a 28 years Paral woman due to acute renal failure (ARF) following lower segment caesarian section (LSCS) for severe preeclampsia with 
abruptio placenta. Total number of live births (LB) were $70(62.5 \%)$ among which 28 (40\%) required neonatal admission and 3 had early neonatal death (NND) (Table 4).

\begin{tabular}{|c|c|c|c|c|}
\hline $\begin{array}{l}\text { Maternal } \\
\text { and } \\
\text { Perinatal } \\
\text { Outcome }\end{array}$ & & $\begin{array}{l}\text { Deli- } \\
\text { vered } \\
\text { at } \\
\text { TUTH }\end{array}$ & $\begin{array}{l}\text { Deli- } \\
\text { vered } \\
\text { outside }\end{array}$ & $\begin{array}{l}\text { Total } \\
\%\end{array}$ \\
\hline \multirow[t]{2}{*}{$\begin{array}{l}\text { Maternal } \\
\text { Outcome }\end{array}$} & $\begin{array}{l}\text { Patients } \\
\text { Improved }\end{array}$ & 104 & 6 & $\begin{array}{l}110 \\
(98.22)\end{array}$ \\
\hline & $\begin{array}{l}\text { Maternal } \\
\text { mortality }\end{array}$ & - & 2 & $2(1.78)$ \\
\hline \multirow{8}{*}{$\begin{array}{l}\text { Pregnancy } \\
\text { /Perinatal } \\
\text { outcome }\end{array}$} & $\begin{array}{l}\text { Live birth } \\
\text { (LB) }\end{array}$ & 66 & 4 & $\begin{array}{l}70 \\
(62.5)\end{array}$ \\
\hline & $\begin{array}{l}\text { Still } \\
\text { birth }\end{array}$ & 2 & 2 & $\begin{array}{l}4 \\
(3.5)\end{array}$ \\
\hline & IUFD & 15 & 2 & $\begin{array}{l}17 \\
(15.17)\end{array}$ \\
\hline & $\begin{array}{l}\text { Not } \\
\text { delivered }\end{array}$ & 11 & - & $\begin{array}{l}11 \\
(9.82)\end{array}$ \\
\hline & $\begin{array}{l}\text { Ectopic. } \\
\text { Abortus }\end{array}$ & 10 & & $\begin{array}{l}10 \\
(9)\end{array}$ \\
\hline & $\begin{array}{l}\text { Neonatal } \\
\text { admission }\end{array}$ & 28 & - & $\begin{array}{l}28 \\
(40 \% \\
\text { of LB) }\end{array}$ \\
\hline & $\begin{array}{l}\text { APGAR } \\
<7 \text { in } \\
1 \mathrm{~min}\end{array}$ & 20 & - & $\begin{array}{l}20(29 \% \\
\text { of LB) }\end{array}$ \\
\hline & NND & 3 & - & $\begin{array}{l}3(4.28 \% \\
\text { of LB) }\end{array}$ \\
\hline
\end{tabular}

\section{DISCUSSION}

In the present study obstetric referred cases accounted for $2.6 \%$ of the total admissions in the Department of Obstetrics and Gynaecology which was consistent with the study conducted by Ohn et al. ${ }^{2}$ Fifty one percent came from rural area and $48.2 \%$ from urban area whereas Rathi et al reported $67 \%$ of the referrals from urban areas. ${ }^{3}$ Most common diagnosis among the referrals was medical disorders complicating pregnancy (37.5\%) among which cardiac disease accountted for $19.64 \%$, followed by hypertensive disorder which was $16 \%$ in the present study. This is comparable to results reported by Ohn et al in which gestational hypertention was the most common indication (18.5\%) for referral. ${ }^{2}$ In another study done by Rathi et al $26 \%$ were referred for hypertensive disorders of pregnancy, $26 \%$ for preterm labour and $21 \%$ medical disorders complicating pregnancy. ${ }^{3}$ Hypertensive disorder was main indication of referral in another study also done by Shilpa and Anand. ${ }^{4}$ However, leading conditions of referral were different in other studies such as premature rupture of membranes, non progress of labour and grand multipara. ${ }^{5-10}$ The disparity from these studies might be because TUTH being the tertiary multidisciplinary hospital received medical disorder (heart disease) complicating pregnancy the maximum. Presence of a cardiac centre with intensive care facilities results in many referrals for pregnancy with cardiac diseases at this institute. Lack of advanced cardiac facility or physicians, lack of tertiary level care with multidisciplinary facility might be the possible reasons for referrals to this institute from the various centers especially from outside Kathmandu.

In present study, majority of referrals were during antenatal period (55.35\%), followed by

intranatal (28.57\%), early pregnancy (9\%) and postnatal $(7.14 \%)$ which is similar to Ohn et al. ${ }^{2}$ However, another study done by Patel et al found that majority of referrals were during intranatal period (64.5\%), followed by antenatal (23.9\%). ${ }^{10}$ They had done the study in rural area where women seeking obstetric care directly in intranatal period was more common where as both Ohn et al and present study was done in urban hospital area which received patients in antenatal period more than in intranatal period.

In this study, $25.89 \%$ required blood and blood products transfusion whereas according to Rathi et al, $42 \%$ patients required blood or blood product transfusion. Higher incidence of PPH in her study was responsible for this high percentage of transfusion. ${ }^{3}$ In another study done by Khatoon et al, the figure was $35 \% .{ }^{11}$ In contrast, only $2.2 \%$ of patients, required transfusions in a study done by Ohn et al. ${ }^{2}$

Intensive care management was required in $18.75 \%$ of cases in present study. However, in a study done by Rathi et al and Sabale and Patankar, only $8 \%$ and $0.79 \%$ patients respectively required intensive care, ${ }^{12}$ possible explanation again being TUTH a tertiary referral hospital which received more cardiac patients (19.64\%), and $26.78 \%$ of patients were serious or critical on arrival requiring intensive monitoring.

There were 2 mortalities during the study period. One was in 34 year Para4+1 woman because of secondary $\mathrm{PPH}$ with sepsis following home delivery and managed conservatively by health worker at home which was later on taken to nearby health post on $10^{\text {th }}$ post partum day and then ultimately referred to 
TUTH. She arrived after 10 days of starting problems. Family members' lack of awareness, poor financial status, arriving TUTH late are the contributing factors for the mortality. Another was in 28 years Para1 woman due to ARF following LSCS for severe preeclampsia with abruptio placenta, referred from medical college outside Kathmandu after no sign of improvement despite their management for few days. Whether early referral could have saved this woman or not is still an unanswerable query. Obstetric haemorrhage, sepsis and toxaemia- the main three components of classic triad of causes of maternal mortality in developing countries- were reasons of mortality of these two women too. The percentage of mortality of present study (1.73\%) is comparable to Khatoon et al (2.55\%). ${ }^{11}$

In this study total number of live births were 70 (62.5\%), intra uterine fetal death 17 (15.17\%). while 4 (3.5\%) were still births. Among these live births 28 (40\%) required neonatal admission and 3 (4.29\%) had NND. The percentage of nursery care and NND is quite high in other studies. ${ }^{3,10}$ This might reflect that the perinatal facility is probably better in this hospital for which most of the patients (24\%) were referred from other centers.

\section{CONCLUSIONS}

Wide spectrums of complicated obstetric cases were referred to this hospital. Unavailability of perinatal facility was the most common reason for referral followed by unavailability of physician. Most common diagnosis at the time of referral was medical disorders complicating pregnancy (37.5\%). Fifty two percentage patients required surgical management and $19 \%$ required intensive care management. Twenty seven percentages of cases were in serious or critical condition on admission and 98\% improved and were discharged. Timely referrals with detailed referral slips or prior information of referred cases might help in early and optimal intervention so that both major morbidities and mortalities can be avoided. A structured referral system would help both patient and doctor in providing essential life saving care.

\section{DISCLOSURE}

The authors report no conflicts of interest in this work. No violation of human rights and safety.

Funding: Nil

\section{REFERENCES}

1. American Hospital Association; (2003-02-01). AHA : Advisory : HIPAA Updated Guidelines for Releasing Information on the Condition of Patients. American Hospital Association. Retrieved and archived on 2008-01-28.

2. Ohn HT, Patrick DC, Zaw W, Mary K, Hnin YK, Herni B. Inter-hospital emergency obstetric referrals to the labour ward of RIPAS Hospital Brunei Int Med J. 2011; 7(1): 22-33

3. Rathi C, Gajria K, Soni N. Review of referred obstetric cases - Maternal and Perinatal Outcome. Bombay Hosp J. 2010; 52(1): 52-6

4. Shilpa SB, Anand PK. Study of obstetric referrals to teaching institute. Indian J Appl Res. 2013; 3(7), 469-71

5. Patterson JA, Foureur M, Skinner JP. Patterns of transfer in labour and birth in rural New Zealand. Rural and Remote Health. 2011; 11(2): 1710 .

6. Brun JL, Billeaud C, Elleau C, Guyon F, Roux D, Dallay D et al. Maternal transport to the Bordeaux University Hospital: a retrospective study of 263 cases (1996-1998). J Gynecol Obstet Biol Reprod. 2000; 29(4): 414-22.
7. Swain S, Prakash A. Utilisation of referral services by high risk pregnant population in rural Varanasi. Indian J Matern Child Health. 1992; 3(3): 74-6.

8. Strand RT, de Campos PA, Paulsson G, de Oliveira J, Bergström $\mathrm{S}$, Audit of referral of obstetric emergencies in Angola: a tool for assessing quality of care. Afr J Reprod Health 2009; 13(2): 75-85.

9. Nkyekyer K. Peripartum referrals to Korle $\mathrm{Bu}$ Teaching Hospital, Ghana-a descriptive study. Trop Med Int Health. 2000; 5(11): 811-17.

10. Patel HC, Singh BB, Moitra M, Kantharia SL. Obstetric referrals: scenario at a primary health centre in Gujarat. National J Comm Med. 2012; 3(4): 711-14.

11. Khatoon A, Hasny SF, Irshad S, Ansari J. An audit of obstetrics referrals to Abbasi Shaheed Hospital. Pak J Surg. 2011; 27(4): 304-8.

12. Umesh Sabale, Alka Murlidhar Patankar. Study of Materna and Perinatal Outcome in Referred Obstetrics Cases. J of Evolution of Med and Dent Sci. 2015; 4(26):4448-55. 